\title{
Comparison of Cellulose Decomposition by Microwave Plasma and Radio Frequency Plasma
}

\author{
Katsuya Konno $^{1,2}$, Hajime Onodera ${ }^{2}$, Kazuhisa Murata ${ }^{3}$, Kaoru Onoe ${ }^{2}$, Tatsuaki Yamaguchi ${ }^{2 *}$ \\ ${ }^{1}$ Hitachi Automotive Systems, Ltd, Development Div. Drive Control Systems Div. 6-3, \\ 1-Chome Fujimi, Kanagawa, Japan \\ ${ }^{2}$ Department of Life and Environmental Sciences, Faculty of Engineering, \\ Chiba Institute of Technology, Chiba, Japan \\ ${ }^{3}$ National Institure of Advanced Industrial Science and Technology (AIST), \\ AIST Tsukuba Central 5, Ibaraki, Japan \\ E-mail: *tatsuaki.yamaguchi@it-chiba.ac.jp
}

Received June 28, 2011; revised July 29, 2011; accepted August 5, 2011

\begin{abstract}
Biomass conversion by plasma has the advantage of mainly producing gaseous products, $\mathrm{H}_{2}, \mathrm{CO}$ and $\mathrm{CO}_{2}$. Though the thermal plasma has been used for this conversion, the plasma temperature is too high to be unfit for the conversion biomass. The temperature of cold plasma, however, is lower under $3000 \mathrm{~K}$. It expects to be adequate for biomass conversion. Cold plasma can be obtained with irradiation microwave $(2.45 \mathrm{GHz}) \mathrm{or}$ radio frequency $(13.5 \mathrm{MHz})$ under reduce gas pressure. Therefore, in present study, the effective decomposition of cellulose by microwave plasma (MWP) and radio frequency plasma (RFP) is examined. The conversion of cellulose by MWP $\left(\mathrm{X}_{\mathrm{MWP}}\right)$ is higher than that by RFP $\left(\mathrm{X}_{\mathrm{RFP}}\right)$, irrespective of the reaction time. $\mathrm{X}_{\mathrm{MWP}}$ and $\mathrm{X}_{\mathrm{RFP}}$ reach $92.8 \mathrm{wt} \%$ at $10 \mathrm{~min}$ and $68.1 \mathrm{wt} \%$ at $30 \mathrm{~min}$. The maximum yield of gaseous products ( $\mathrm{Y}_{\text {gas }}$ ) by MWP is $85.1 \mathrm{wt} \%$ at $10 \mathrm{~min}$, higher by $23.2 \mathrm{wt} \%$ than $\mathrm{Y}_{\text {gas }}$ by RFP at $30 \mathrm{~min}$. The amount of $\mathrm{H}_{2}$ and $\mathrm{CO}$ obtained by MWP is $18.0 \mathrm{mmol} / \mathrm{g}$ and $23.5 \mathrm{mmol} / \mathrm{g}$, it is larger than that obtained by RFP. Comparing the relationship between conversion and yield, $\mathrm{Y}_{\text {gas }}$ of MWP is slightly higher than that of RFP under X of 60 $\mathrm{wt} \%$, and both $\mathrm{Y}_{\text {gas }}$ is almost same over $60 \mathrm{wt} \%$. The amount of $\mathrm{H}_{2}$ and $\mathrm{CO}$ obtained by MWP is larger by $9.3 \mathrm{mmol} / \mathrm{g}$ and $9.6 \mathrm{mmol} / \mathrm{g}$ than that obtained by RFP. C, $\mathrm{H}$ and $\mathrm{O}$ element in cellulose is mainly distributed to $\mathrm{H}_{2}$ and $\mathrm{CO}$ by MWP. RFP mainly distributes $\mathrm{H}$ and $\mathrm{O}$ element to the other gases without $\mathrm{H}_{2}$ and $\mathrm{CO}$. In addition, a large amount of $\mathrm{C}$ element is remains in the residue. Those results is found that MWP was more suitable for cellulose gasification than RFP, since MWP can highly convert $\mathrm{C}, \mathrm{H}$ and $\mathrm{O}$ element to $\mathrm{H}_{2}$ and $\mathrm{CO}$ by higher energy of microwave frequency in comparison with radio frequency.
\end{abstract}

Keywords: Microwave Plasma, Radio Frequency, Plasma, Cellulose

\section{Introduction}

Recently, renewable energy is noticed again following reasons: 1) soaring the price of petroleum; 2) the uncertain supply of petroleum; 3) a crisis at the Fukushima No. 1 nuclear power plant. Biomass is a renewable resource by the photosynthesis of $\mathrm{H}_{2} \mathrm{O}$ and $\mathrm{CO}_{2}$, and biomass widely exists distribution on the earth. The abundance of unused biomass is exists in the field of agriculture, forestry and livestock industry. If those resources convert to the energy resource, for example hydrogen for fuel cell, it will become an expecting technique.

Plasma is considered to be the $4^{\text {th }}$ state of matter, it is gas including ion, electron and neutral particle. Plasma is roughly classified in thermal plasma and cold plasma. Because thermal plasma is equilibrium state of the temperature of electron, ion and neutral particle, the temperature of thermal plasma becomes as high as $3000 \mathrm{~K}$ $10000 \mathrm{~K}$. Therefore, plasma method has the advantage of the possible abundance production of $\mathrm{H}_{2}$ and $\mathrm{CO}$ from biomass, and gaseous products obtained by plasma contain low tar [1]. Katou et al. reported that the tar yield was low and $\mathrm{H}_{2}, \mathrm{CO}$ and $\mathrm{CO}_{2}$ were obtained when biomass was converted by DC arc plasma, which is thermal plasma [2]. But the temperature of thermal plasma is too high to be unfit for the energy efficient conversion of 
biomass.

Cold plasma is non-equilibrium state of the temperature of electron, ion and neutral particle. The electron temperature is only higher than ion and neutral particle temperature. Therefore, plasma temperature is under $3000 \mathrm{~K}$, which might be adequate for the conversion of biomass to gaseous products. Tang et al. studied that the gasification of rice straw by RF plasma (RFP), which was obtained under $3-8 \mathrm{kPa}$ at $1600-2000 \mathrm{~W}$ of power by the irradiation of radio frequency $(13.56 \mathrm{MHz})$. In their results, the yield of gaseous products reached at $66 \%$ and $\mathrm{H}_{2}, \mathrm{CO}, \mathrm{CH}_{4}$ and $\mathrm{CO}_{2}$ was mainly obtained [3].

It has been studied in our laboratory that the effective conversion of coal (Yallourn coal and Taiheiyo coal) [4-6] and biomass (cellulose, lignin, saw dust, sugar cane bagasse) [7-9] by microwave plasma (MWP) are performed under reduce pressure by microwave $(2.45 \mathrm{GHz})$, generated by a for lower electric power $(300 \mathrm{~W})$ than the above mentioned works. When cellulose was used as a raw material, the yield of gaseous products $\left(\mathrm{Y}_{\text {gas }}\right)$ reached at $79 \mathrm{wt} \%$ and $\mathrm{H}_{2}$ and $\mathrm{CO}$ was mainly obtained [7]. Com-paring those results with that obtained at same temperature of MWP by conventional pyrolysis, $\mathrm{Y}_{\text {gas }}$ obtained by MWP is higher by $67.7 \mathrm{wt} \%$ than that obtained by conventional pyrolysis. Mainly $\mathrm{CO}_{2}$ was obtained at $620 \mathrm{~K}, \mathrm{CO}$ and $\mathrm{CO}_{2}$ were obtained in the range from $1000 \mathrm{~K}-1050 \mathrm{~K}$, and $\mathrm{H}_{2}, \mathrm{CO}$ and $\mathrm{CO}_{2}$ were obtained over $1100 \mathrm{~K}$ by conventional pyrolysis [7].

Both cold plasma methods can give the high yield of gaseous products and produce mainly $\mathrm{H}_{2}$ and $\mathrm{CO}$. The difference between microwave plasma and RF plasma is the frequency of electromagnetic wave for obtained plasma. As the difference of energy is depend on the frequency of electromagnetic, the plasma density, the electron state and the activated species might be different between MWP and RFP. It is considered that this affects the decomposition of biomass.

In present study, the decomposition of cellulose by MWP and RFP was compared under Ar at irradiation power of $300 \mathrm{~W}$.

\section{Method of Gasification by Plasma}

\subsection{Raw Material}

Cellulose (Merck Co., 200 mesh under), which is main composition of biomass, was used as raw material. The proximate and elemental analysis of cellulose was summarized in Table 1. Cellulose was dried under argon at $110^{\circ} \mathrm{C}$ for 3 hours.

\subsection{Plasma Apparatus}

\subsubsection{Plasma Reactor with Radio Frequency}

Figure 1(a) shows the radio frequency plasma appa-
Table 1. Proximate and elemental analysis of cellulose.

\begin{tabular}{ccccccccccc}
\hline \multicolumn{1}{c}{ Proximate analysis (d.b) Elemental analysis (d.a.f) Molar ratio } \\
& $\begin{array}{c}{[\mathrm{wt} \%]} \\
\text { VM }\end{array}$ & Ash & FC & C & H & N & O(diff) & H/C & O/C \\
\hline Cellulose & 95.5 & 0.0 & 4.5 & 42.6 & 6.2 & 0.0 & 51.2 & 1.75 & 0.90 \\
\hline
\end{tabular}

ratus. A low-pressure flow reactor was used with a quartz glass reaction tube $(12 \mathrm{~mm}$ of internal diameter and 600 $\mathrm{mm}$ of length). Cellulose was packed in the middle of the vertical reaction tube. The radio frequency (RF) was introduced at $13.56 \mathrm{GHz}$ from two ring copper electrode to produce a plasma in the reaction tube. The space of between two electrodes was $17 \mathrm{~mm}$.

\subsubsection{Plasma Reactor with Microwave}

Figure 1(b) shows the microwave plasma apparatus. A low-pressure flow reactor was used with a quartz glass reaction tube $(25 \mathrm{~mm}$ of internal diameter and $800 \mathrm{~mm}$ of length). Cellulose was packed in the middle of the vertical reaction tube. The microwaves (MW) were introduced at $2.45 \mathrm{GHz}$ from the side of the tube via a wave guide to produce a plasma in the reaction tube.

\subsection{Experimental Conditions}

Experimental conditions of MWP and RFP are summarized in Table2.

\subsection{Calculation of Conversion and Product Yield}

The conversion $(\mathrm{X})$ and the yield $(\mathrm{Y})$ were calculated, based on the weight decrease of the post-reaction residues dried at $380 \mathrm{~K}$ for $3 \mathrm{~h}$. The yield of the liquid products was also calculated, based on the weight difference, before and after extraction with benzene. Equations are showed as follows.

$$
\begin{aligned}
& \mathrm{X}=\left(\mathrm{W}_{0}-\mathrm{W}_{\text {residue }}\right) / \mathrm{W}_{0} \times 100 \\
& \mathrm{Y}_{\text {gas }}=\left(\mathrm{W}_{0}-\left(\mathrm{W}_{\text {liquid }}+\mathrm{W}_{\text {residue }}\right)\right) / \mathrm{W}_{0} \times 100 \\
& \mathrm{Y}_{\text {liquid }}=\mathrm{W}_{\text {liquid }} / \mathrm{W}_{0} \times 100
\end{aligned}
$$

$\mathrm{X}$ : conversion ( $\mathrm{X}_{\mathrm{MWP}}$ : conversion by microwave plasma, $\mathrm{X}_{\mathrm{RFP}}$ : conversion by RFP)

$\mathrm{Y}_{\text {gas }}$ : yield of gaseous products

$\mathrm{Y}_{\text {liquid: }}$ yield of liquid products

$\mathrm{W}_{0}$ : weight of cellulose

$\mathrm{W}_{\text {residue }}$ : weight of residue ,

$\mathrm{W}_{\text {liquid}}$ : weight of liquid products

\subsection{Analysis of Products}

On-line gas chromatography (SHIMADZU Co. Ltd, GC- 


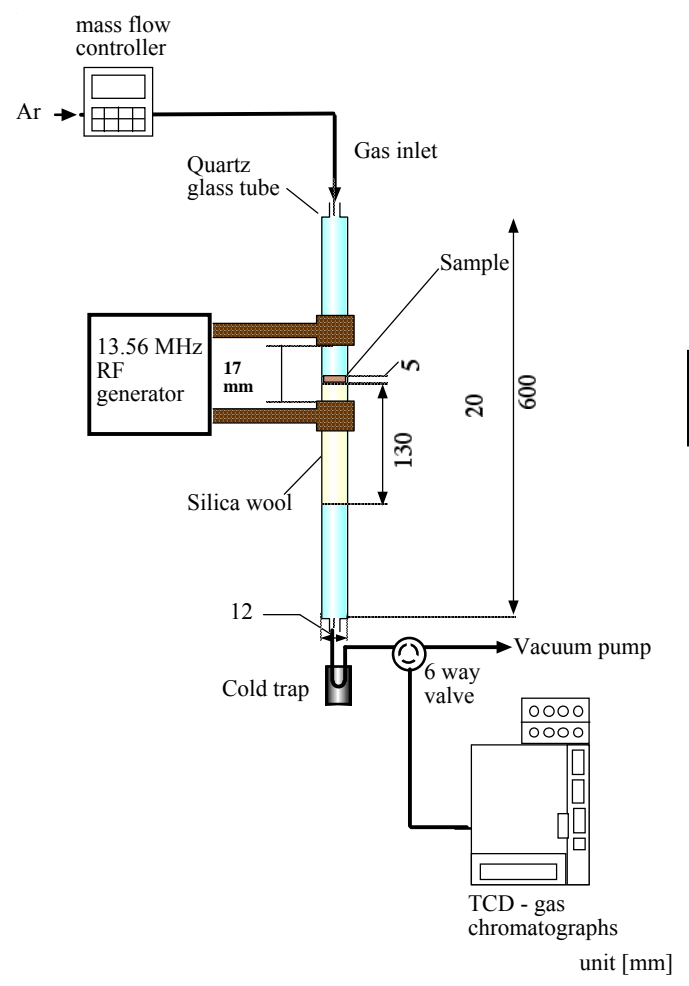

(a)

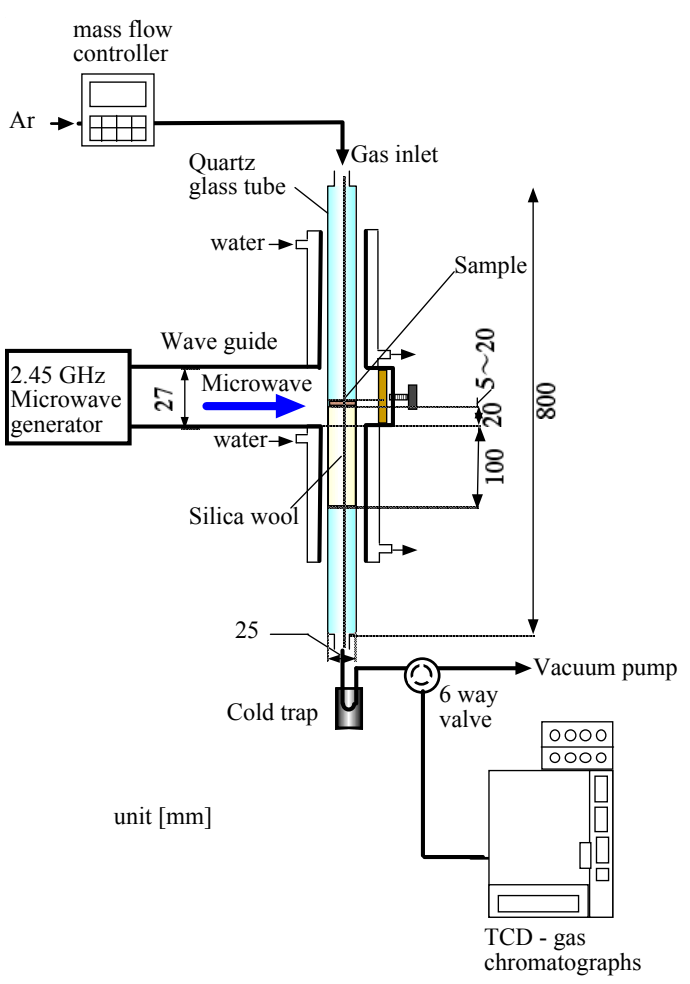

(b)

Figure 1. Plasma reactor. (a) Radio frequency plasma reactor; (b) Microwave plasma reactor.

Table 2. Experimental conditions.

\begin{tabular}{|c|c|c|}
\hline Method & Radio frequency plasma & Microwave plasme \\
\hline \multicolumn{3}{|l|}{ I Sample } \\
\hline Raw material & Cellulose (March Co.) & Cellulose (March Co.) \\
\hline Mesh & $<200$ mesh & $<200$ mesh \\
\hline weight & $1.0 \mathrm{~g}$ & $1.5 \mathrm{~g}$ \\
\hline \multicolumn{3}{|l|}{ II Gas } \\
\hline Feed gas & $\operatorname{Ar}(99.999 \%)$ & $\operatorname{Ar}(99.999 \%)$ \\
\hline Feed rate & $0.45 \mathrm{mmol} / \mathrm{min}$ & $0.89 \mathrm{mmol} / \mathrm{min}$ \\
\hline Initial pressure & $1.3 \mathrm{kPa}$ & $4.0 \mathrm{kPa}$ \\
\hline \multicolumn{3}{|l|}{ III Electromagnetic wave } \\
\hline Frequency & $13.56 \mathrm{MHz}$ & $2.45 \mathrm{GHz}$ \\
\hline Power & $300 \mathrm{w}$ & $300 \mathrm{w}$ \\
\hline Irradiation time & $1-30 \mathrm{~min}$ & $0.5-10 \mathrm{~min}$ \\
\hline
\end{tabular}

14B) was used for the analysis of the gaseous products. The element analysis of residue was measured with CHN coder (Yanaco Co., MT-6)

\section{Results and Discussion}

\subsection{Comparison of the Effect of Time Change on Reaction}

\subsubsection{Comparison of Conversion and Products Yield}

Figure 2 shows the relationship between reaction time (t) and $\mathrm{X} . \mathrm{X}_{\mathrm{MWP}}$ immediately increases until $5 \mathrm{~min}$ and is constant at $92.8 \mathrm{wt} \%$ after $5 \mathrm{~min}$. $\mathrm{X}_{\mathrm{RFP}}$ gently increases until $15 \mathrm{~min}$ and is constant at $65 \mathrm{wt} \%$ after $15 \mathrm{~min}$. Comparing $\mathrm{X}_{\mathrm{MWP}}$ with $\mathrm{X}_{\mathrm{RFP}}, \mathrm{X}_{\mathrm{MWP}}$ is higher than $\mathrm{X}_{\mathrm{RFP}}$ irrespective of $t$. This shows that the conversion rate of MWP is faster than that of RFP. From this result, it is found that MWP can convert cellulose in the short time and indicates high conversion.

Figure 3 shows the relationship between $t$ and $Y_{\text {gas }}$, $\mathrm{Y}_{\text {liquid. }} \mathrm{Y}_{\text {gas }}$ by MWP reaches $86 \mathrm{wt} \%$ at $10 \mathrm{~min}$. $\mathrm{Y}_{\text {liquid }}$ by MWP indicates the maximum value of $13 \mathrm{wt} \%$ at $5 \mathrm{~min}$. $\mathrm{Y}_{\text {gas }}$ by RFP increases until $15 \mathrm{~min}$ and is constant at 65 wt $\%$ after $15 \mathrm{~min}$. $\mathrm{Y}_{\text {liquid }}$ by RFP indicates the maximum 


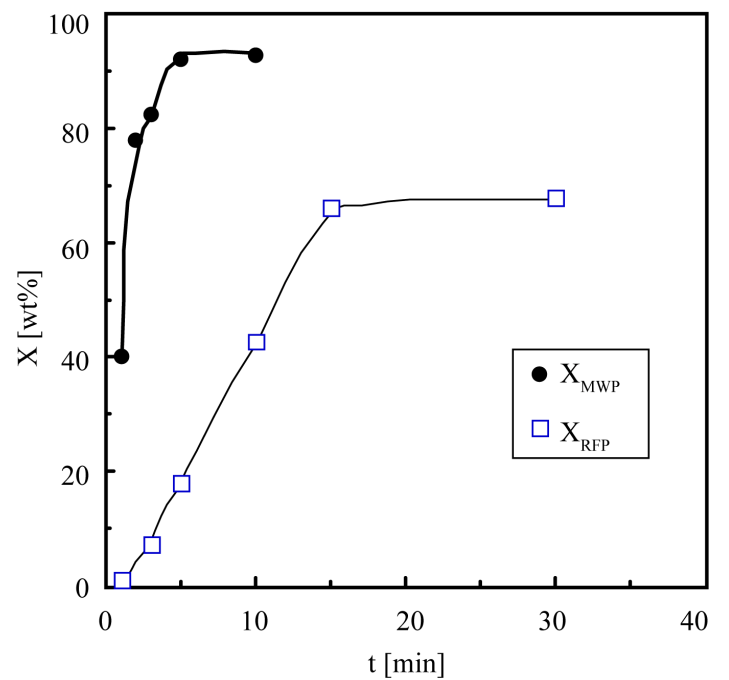

Figure 2. Comparison of the conversion with the time change.

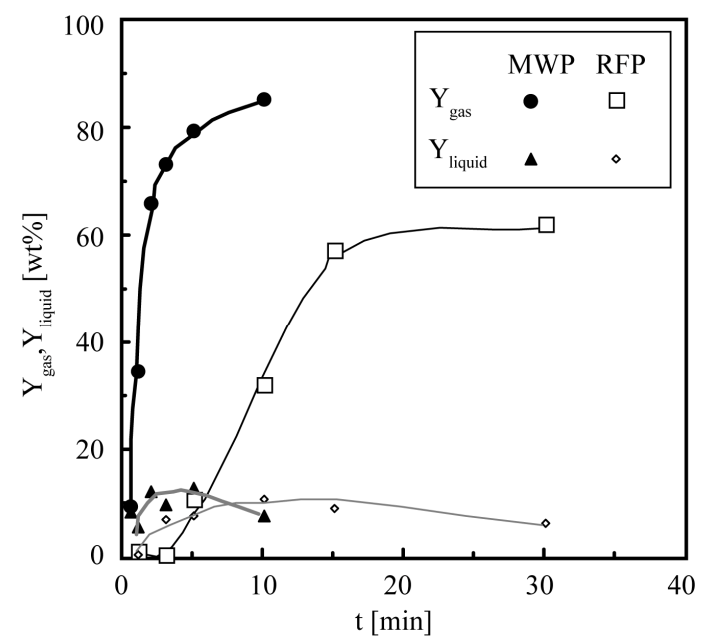

Figure 3. Comparison of the product yield with the time change.

value of $11 \mathrm{wt} \%$ at $10 \mathrm{~min}$. Comparing $\mathrm{Y}_{\text {gas }}$ and $\mathrm{Y}_{\text {liquid }}$ by MWP with that by RFP, main products is gas irrespective of $t$, and $Y_{\text {gas }}$ by MWP is higher than that of RFP irrespective of $t$. This result shows the gasification rate of MWP is faster than that of RFP and the maximum $Y_{\text {gas }}$ by MWP is higher than that by RFP. From above those results, it is found that the maximum value, conversion rate and $Y_{\text {gas }}$ rate are different by frequency. This is probably due to the higher temperature of MWP in comparison of the temperature of RFP. It may be cause of the difference energy by frequency and the plasma state obtained by different of frequency. The decomposition of biomass by pyrolysis generally indicates higher conversion and $\mathrm{Y}_{\text {gas }}$ with an increase in temperature. The energy of MW is larger than that of RF, because the frequency of MW $(2.45 \mathrm{GHz})$ is larger than that of RF $(13.56 \mathrm{MHz})$. In addition, the different frequency caused the change of a plasma density. As the frequency of MW is higher than that of RF, the plasma density of MW should be higher than that of RF. In high plasma density, electron, ion and neutral particle easily collide to each other. Therefore, gas temperature of MWP is assumed to be high. We measured the temperature of graphite heated by $\mathrm{Ar}$ plasma obtained under 1 torr at $300 \mathrm{~W}$ by MW. The temperature reached $1074 \mathrm{~K}$ until $3 \mathrm{~min}$ and was constant over 5 min. On the other hand, the temperature of $\mathrm{N}_{2}$ plasma obtained under 1 torr at $308 \mathrm{~W}$ by RF was $783 \mathrm{~K}$ [10]. It is suggested that the difference of conversion and $\mathrm{Y}_{\text {gas }}$ between MWP and RFP results from the different plasma temperature by a frequency.

\subsubsection{Comparison of the Amount of Gaseous Products}

Figure 4 shows the relationship between $t$ and the amount of gaseous products. The component of gaseous products obtained by MWP is mainly $\mathrm{H}_{2}$ and $\mathrm{CO}$, and the others are a few $\mathrm{CH}_{4}, \mathrm{CO}_{2}, \mathrm{C}_{2} \mathrm{H}_{2}$ and $\mathrm{C}_{2} \mathrm{H}_{4}$. The amount of $\mathrm{H}_{2}$ and $\mathrm{CO}$ increases with an increase in $\mathrm{t}$ and indicates a maximum value at $10 \mathrm{~min}$. The amount of $\mathrm{H}_{2}$ and $\mathrm{CO}$ is $18.0 \mathrm{mmol} / \mathrm{g}$ and $23.5 \mathrm{mmol} / \mathrm{g}$ at $10 \mathrm{~min}$. The component of gaseous products obtained by RFP is mainly $\mathrm{H}_{2}$ and $\mathrm{CO}$, and the others are a few $\mathrm{CH}_{4}, \mathrm{CO}_{2}$, $\mathrm{C}_{2} \mathrm{H}_{2}, \mathrm{C}_{2} \mathrm{H}_{4}$ and $\mathrm{C}_{2} \mathrm{H}_{6}$. The amount of $\mathrm{H}_{2}$ and $\mathrm{CO}$ increases with an increase in $\mathrm{t}$ and indicates maximum value at $30 \mathrm{~min}$. The amount of $\mathrm{H}_{2}$ and $\mathrm{CO}$ is $8.7 \mathrm{mmol} / \mathrm{g}$ and $13.9 \mathrm{mmol} / \mathrm{g}$ at $30 \mathrm{~min}$. The amount of $\mathrm{H}_{2}$ and $\mathrm{CO}$ obtained by MWP is larger than that obtained by RFP irrespective of $t$. It is found that MWP can produce the large amount of $\mathrm{H}_{2}$ and $\mathrm{CO}$ in the short time of $10 \mathrm{~min}$. This results from the higher temperature of MWP than that of RFP. Producing syngas $\left(\mathrm{H}_{2}\right.$ and $\left.\mathrm{CO}\right)$ from biomass by a general pyloysis, Dufour et al. reported the amount of hydrogen obtained from wood increased from $0.06 \mathrm{Nm}^{3} / \mathrm{kg}$ to $0.24 \mathrm{Nm}^{3} / \mathrm{kg}$ with an increase in temperature from $700^{\circ} \mathrm{C}$ to $1000^{\circ} \mathrm{C}$ [11]. It is suggested that the obtained large amount of $\mathrm{H}_{2}$ and $\mathrm{CO}$ by MWP is probably due to the high temperature.

\subsection{Comparison of the Product Yield with the Conversion Change}

Figure 5 shows the relationship between $X$ and $Y_{\text {gas }}$, $\mathrm{Y}_{\text {liquid. }} \mathrm{Y}_{\text {gas }}$ increase with an increase in $\mathrm{X}$ irrespective of method. Under $60 \mathrm{wt} \%$ of $\mathrm{X}, \mathrm{Y}_{\text {gas }}$ by MWP is higher than as that of RFP. Over $60 \mathrm{wt} \%$ of $\mathrm{X}, \mathrm{Y}_{\text {gas }}$ by MWP is almost same as that by RFP. $Y_{\text {liquid }}$ is constant irrespective of X. Y $\mathrm{Y}_{\text {liquid }}$ by MWP is lower than that of RFP under $60 \mathrm{wt} \%$ of $X$. From this result, it is found that $Y_{\text {gas }}$ is almost same over $X$ of $60 \mathrm{wt} \%$ irrespective of method.

Park et al. proposed decomposition mechanism of wood pyrolysis and obtained activation energy [12]. Ac- 


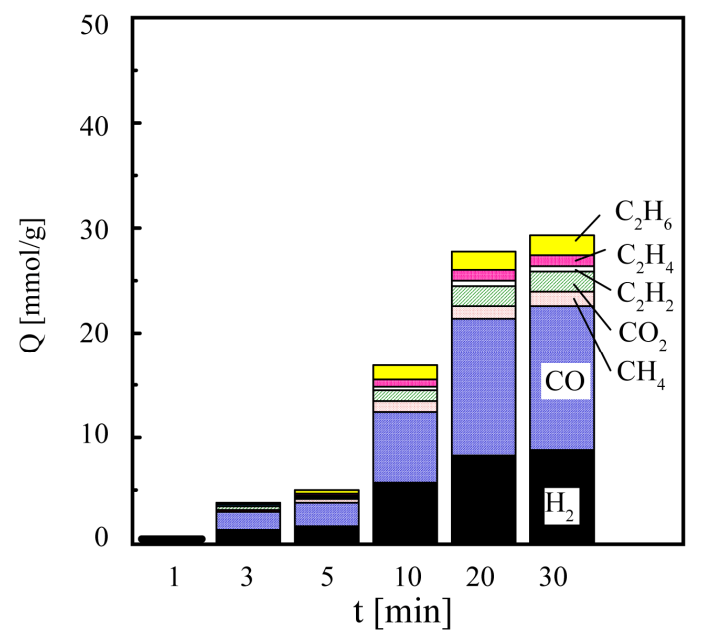

(a)

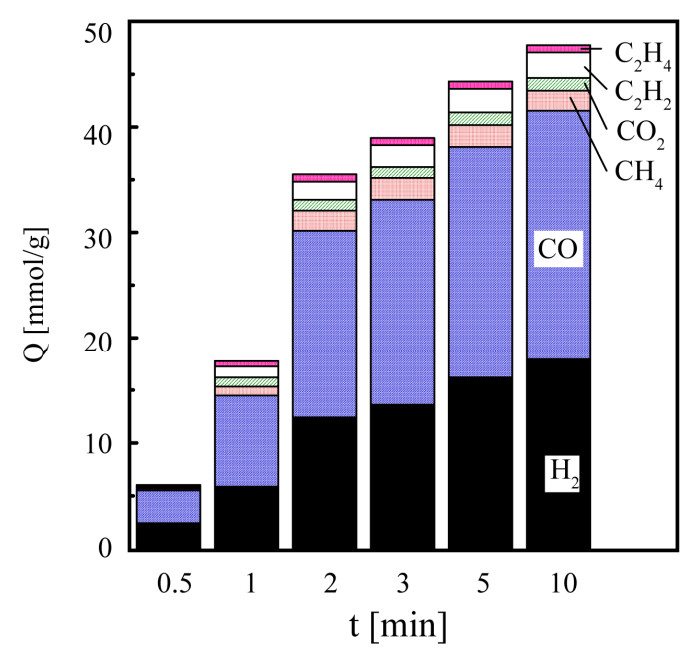

(b)

Figure 4. Comparison of the amount of gaseous products. (a) Radio frequency plasma; (b) Microwave plasma.

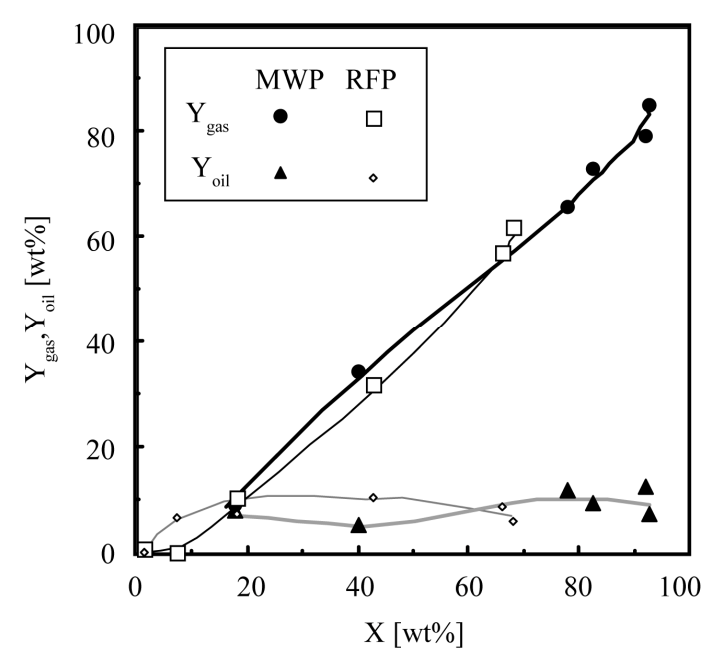

Figure 5. Relationship between conversion and product yield ( $\left.\mathbf{Y}_{\text {gas }}, \mathbf{Y}_{\text {liquide }}\right)$. cording to their results, gas was produced directly from wood or obtained from the decomposition of tar produced by wood pyrolysis. Moreover, they investigated activation energy (E) of the each decomposition process, E of wood to gas was $152.7 \mathrm{~kJ} / \mathrm{mol}$, E of wood to tar was $148 \mathrm{~kJ} / \mathrm{mol}$, and $\mathrm{E}$ of tar to gas was $108 \mathrm{~kJ} / \mathrm{mol}$. Those results are found directly gasification from wood needed large energy and production of tar was easier than that of gas. Moreover, obtained tar was easily converted to gas. It is suggested that the higher $Y_{\text {gas }}$ of MWP than that of RFP under $X$ of $60 \mathrm{wt} \%$ is due to the higher MW energy in comparison with RF energy. Over $X$ of $60 \mathrm{wt} \%, \mathrm{Y}_{\text {gas }}$ of RFP is as same as that of MWP. This is due to the conversion of obtained liquid products to gaseous products.

\subsection{Comparison of the Amount of $\mathrm{H}_{2}$ and $\mathrm{CO}$ with the Change of Gaseous Yield}

Figure 6 shows the relationship between $\mathrm{Y}_{\text {gas }}$ and the amount of $\mathrm{H}_{2}$ or $\mathrm{CO}$. The amount of $\mathrm{H}_{2}$ and $\mathrm{CO}$ increases with an increase in $\mathrm{Y}_{\text {gas }}$ irrespective of method. The amount of $\mathrm{H}_{2}$ and $\mathrm{CO}$ obtained by MWP is larger than that obtained by RFP irrespective of $Y_{\text {gas }}$. This results from the difference of energy between $\mathrm{MW}$ and $\mathrm{RF}$. According to Figure 4, the amount of $\mathrm{CH}_{4}, \mathrm{CO}_{2}, \mathrm{C}_{2} \mathrm{H}_{4}$ and $\mathrm{C}_{2} \mathrm{H}_{6}$ obtained by RFP was larger than that obtained by MWP. Cho et al. studied oxidative coupling of methane with microwave and RF plasma catalytic reaction over transitional metals loaded on ZSM-5 [13]. From their results, comparing product selectivity obtained by MWP with that obtained by RFP when $\mathrm{CH}_{4} / \mathrm{O}_{2}(4: 1)$ was reacted on non-catalyst, $\mathrm{CO}$ selectivity of MWP was higher than that of RFP and $\mathrm{CO}_{2}$ selectivity of MWP was lower than that of RFP. This result was found that CO selectivity is higher with larger energy. This result suggested that the difference of composition of gaseous products between MWP and RFP is due to the difference of energy between MW and RF.

\subsection{Comparison of the Element Distribution}

Figure 7 shows the comparison of the element distribution at the maximum conversion between MWP and RFP. $\mathrm{H}$ and $\mathrm{O}$ element were mainly distributed to gaseous products irrespective of method. By means of MWP, $\mathrm{H}$ element was mainly converted to $\mathrm{H}_{2}$. On the other hand, $\mathrm{H}$ element was mainly distributed to other gases as $\mathrm{CH}_{4}$ and $\mathrm{C}_{2}$ hydrocarbon by using RFP. O element was mainly converted to $\mathrm{CO}$ by using MWP. O element was mainly distributed to other gas as $\mathrm{CO}_{2}$ by using RFP. C element was gasificated to $\mathrm{CO}$ irrespective of method. Although, the large amount of $\mathrm{C}$ element remained in the residue obtained by RFP, and C element remained little in the 


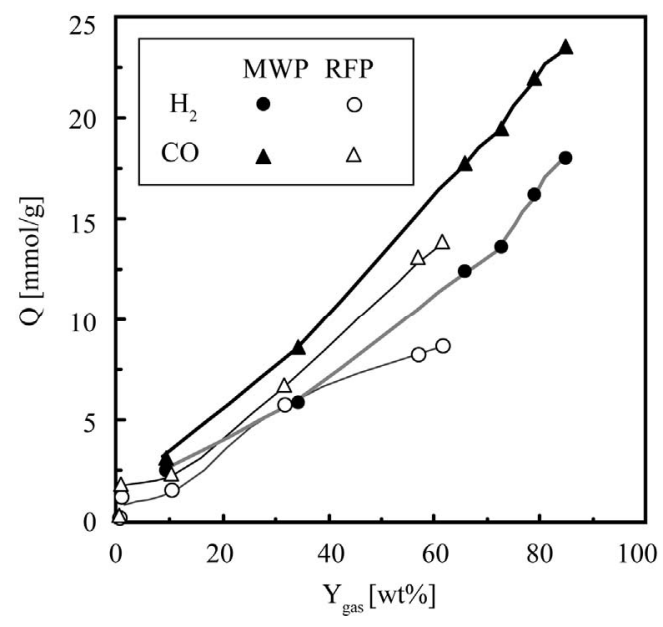

Figure 6. Relationship between conversion and the amount of $\mathrm{H}_{2}, \mathrm{CO}$ in.

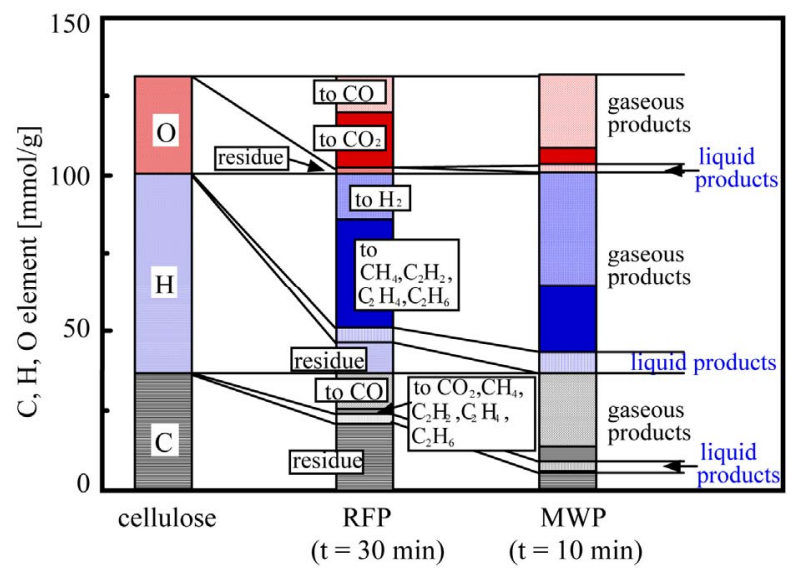

Figure 7 Comparison of element distribution between MWP and RFP.

residue obtained by MWP. Form above result, it is found that MWP can distribute $\mathrm{C}, \mathrm{H}$ and $\mathrm{O}$ element to mainly $\mathrm{H}_{2}$ and $\mathrm{CO}$. This is probably due to the adequate energy of MWP to give active species for $\mathrm{H}_{2}$ and $\mathrm{CO}$.

\section{Conclusions}

MWP can highly convert cellulose to gaseous products at short time $(10 \mathrm{~min})$ in comparison with RFP. Gaseous products mainly comprise $\mathrm{H}_{2}$ and $\mathrm{CO}$. The amount of $\mathrm{H}_{2}$ and CO obtained by MWP is $18.0 \mathrm{mmol} / \mathrm{g}$ and $23.5 \mathrm{mmol} / \mathrm{g}$, it was larger than that obtained by RFP. The gaseous yields by MWP were almost same as that by RFP over X of $60 \mathrm{wt} \%$. However, the amounts of $\mathrm{H}_{2}$ and $\mathrm{CO}$ by MWP were higher than that by RFP irrespective of gaseous yield. By MWP, $\mathrm{C}, \mathrm{H}$ and $\mathrm{O}$ element in cellulose could be converted to mainly $\mathrm{H}_{2}$ and $\mathrm{CO}$. Those results suggest that MWP is suitable for cellulose gasification in comparison with RFP, since MWP highly convert the element of $\mathrm{C}, \mathrm{H}$ and $\mathrm{O}$ to $\mathrm{H}_{2}$ and $\mathrm{CO}$ by the higher energy of microwave frequency than that of radio frequency.

\section{References}

[1] L. hang, C. C. Xu and P. Champagne, "Overview of Recent Advances in Thermo-Chemical Conversion of Biomass," Energy Conversion and Manegement, Vol. 51, No. 5, 2010, pp. 969-982. doi:10.1016/j.enconman.2009.11.038

[2] K. Katou, T. Asou, Y. Karauchi and R. Sameshima, "Melting Municipal Solid Waste Incineration Residue by Plasma Melting Furnace with a Graphite Electrode," Thin Solid Films, Vol. 386, No. 2, 2001, pp. 183-188. doi:10.1016/S0040-6090(00)01640-0

[3] L. Tang and H. Huang," Biomass Gasification Using Capacitively Couples RF Plasma Technology," Fuel, Vol. 84, No. 16, 2005, pp. 2055-2063. doi:10.1016/j.fuel.2005.04.015

[4] O. Kamei, W. Marushima, M. Kobayashi, K. Onoe, T. Yamaguchi, S. Kawai and Y. Ito, "Product Distribution from Yallourn Coal by Methane Microwave Plasma Conversion," Journal of the Japan Petroleum Institute, Vol. 42, No. 5, 1999, pp. 335-341. doi:10.1627/jpi1958.42.335

[5] O. Kamei, W. Marushima, M. Kobayashi, K. Onoe, T. Yamaguchi, S. Kawai and Y. Ito, "Conversion of Yallourn Coal by Microwave Plasma-Effect of Plasma Gas Spiesis on Products," Journal of the Japan Petroleum Institute, Vol. 78, No. 8, 1999, pp. 664-669. doi:10.1016/S0016-2361(98)00055-6

[6] O. Kamei, K. Onoe, W. Marushima and T. Yamaguchi, "Brown Coal Conversion by Microwave Plasma Reactions under Successive Supply of Methane," Fuel, Vol. 77, No. 13, 1998, pp. 1503-1506.

[7] M. Kobayashi, K. Konno, H. Okamura, T. Yamaguchi and K. Onoe, "Decomposition of Biomass by Microwave Plasma Reactions," Journal of the Japan Petroleum Institute, Vol. 84, No. 6, 2005, pp. 468-473.

[8] K. Konno, H. Okamura, M. Kobayashi, K. Onoe and T. Yamaguchi, "Hydrogen Production from Wet Biomass (Lignin) Using Microwave Plasma Technique," Gekkan Kinouzairyou, Vol. 25, No. 1, 2005, pp. 56-61.

[9] K. Konno, M. Kobayashi, K. Onoe and T. Yamaguchi, "Decomposition of Biomass Using Microwave Plasma," The Proceeding of 16th International Symposium on Plasma Chemistry, 2003, S-11.

[10] W.K Tu, J. L Shie, C. Y Chang, C. F. Chang, C. F. Lin, S. Y. Yang, J. T. Kuo, D. G. Shaw and D. J. Lee, "Pyrolysis of Rice Straw Using Radio-Frequency Plasma," Energy and Fuel, Vol. 22, No. 1, 2008, pp. 24-30. doi:10.1021/ef7002848

[11] A. Dufour, P. Girods, E. Masson, Y. Rogaume and A. Zoulalian, "Synthesis Gas Production by Biomass Pyrolysis-Effect of Reactor Temperature on Product Distribution," Hydrogen Energy, Vol. 34, No. 4, 2009, pp. 1726-1734. doi:10.1016/j.ijhydene.2008.11.075 
[12] W.C. Park, A. Atreya and H. R. Baum, "Experimental and Theoretical Investigation of Heat and Mass Transfer Processes during Wood Pyrolysis," Combustion and Flame, Vol. 157, No. 3, 2010, pp. 481-494.

doi:10.1016/j.combustflame.2009.10.006
[13] W. Cho, Y. Baek, S. K. Moon and Y. C. Kim, "Oxidative Coupling Methane with Microwave and RF Plasma Catalytic Reaction over Transitional Metals Loaded on ZSM-5," Catalysis Today, Vol. 74, No. 3-4, 2002, pp. 207-223. doi:10.1016/S0920-5861(02)00030-5 